\title{
Pertumbuhan Kambing Silangan (Anglo-Nubian dan Peranakan Ettawah) yang Diberi Konsentrat dengan Level Protein dan Energi Berbeda
}

\author{
(Growth Performance of Anglo-Nubian and Ettawah Grade Crossbreed Fed \\ Concentrate at Different Levels of Protein and Energy)
}

\author{
Supriyati, Krisnan R, Budiarsana IGM, Praharani L \\ Balai Penelitian Ternak, PO Box 221, Ciawi, Bogor 16002 \\ skompiang@yahoo.co.id
}

\begin{abstract}
The aim of the trial was to evaluate the growth performances of Anglo-Nubian and Ettawah Grade (NE) crossbreed fed concentrate at different levels of protein and energy. Twenty-four young male of NE goats divided into three groups based on their body weights. The experiment was designed by Randomized Completely Block Design with three treatments and eight replications. Three concentrate diets were formulated as follows: $\mathrm{K} 1=15 \% \mathrm{CP}+2.6 \mathrm{Mcal} / \mathrm{kg} \mathrm{ME}$, $\mathrm{K} 2=16 \% \mathrm{CP}+2.8 \mathrm{Mcal} / \mathrm{kg} \mathrm{ME}$ and $\mathrm{K} 3=17 \% \mathrm{CP}+3.0 \mathrm{Mcal} / \mathrm{kg} \mathrm{ME}$, which their ratios of CP to ME were equals. Initial body weights of goats were $14.40 \pm 2.99 \mathrm{~kg} / \mathrm{head}$. Goats were penned individually and given fresh chopped King grass ad libitum, fresh legume mixed (500-800 $\mathrm{g} / \mathrm{head} /$ day) and concentrate ( $2 \%$ of BW) and carried out for 16 weeks. Results showed that different levels of protein and energy at concentrate diets affected $(\mathrm{P}<0.05) \mathrm{DM}$ intake of legume mixed, UIP, DIP, ADF, Ca, and P. Treatment of concentrates did not influence $(\mathrm{P}>0.05)$ growth performance (ADG, FCR), nutrient digestibility and IOFC. In conclusion that growth performance of young male NE goats was not influenced by different levels of protein and energy in the treatments of concentrate diets.
\end{abstract}

Key Words: Energy, Protein, Performances, Crossbred Anglo-Nubian and Ettawah Grade Goats

\begin{abstract}
ABSTRAK
Penelitian ini bertujuan untuk mengetahui kinerja pertumbuhan kambing silangan AngloNubian dan Peranakan Ettawah (NE) yang diberi konsentrat dengan level protein dan energi berbeda. Sebanyak 24 ekor kambing perah NE jantan muda dibagi tiga kelompok berdasarkan bobot badan. Percobaan dirancang secara acak lengkap (RAL) dengan tiga perlakuan dan delapan ulangan. Tiga macam konsentrat diformulasi untuk mendapatkan $\mathrm{K} 1=15 \% \mathrm{PK}+2,6 \mathrm{Mkal} / \mathrm{kg}$ $\mathrm{EM}, \mathrm{K} 2=16 \% \mathrm{PK}+2,8 \mathrm{Mkal} / \mathrm{kg} \mathrm{EM}$ dan $\mathrm{K} 3=17 \% \mathrm{PK}+3,0 \mathrm{Mkal} / \mathrm{kg} \mathrm{EM}$, dengan rasio PK/EM sama. Bobot badan awal kambing adalah $14,40 \pm 2,99 \mathrm{~kg} / \mathrm{ekor}$. Pakan dasar yang diberikan adalah rumput Raja segar ad libitum, 500-800 g/ekor/hari campuran legum segar dan konsentrat sebanyak $2 \%$ BB. Percobaan dilakukan selama 16 minggu. Hasil pengamatan ternyata perlakuan konsentrat yang berbeda level protein dan energi dengan rasio sama, mempengaruhi $(\mathrm{P}<0,05)$ konsumsi harian BK legum, UIP, DIP, SDA, Ca dan P. Perlakuan konsentrat tidak mempengaruhi $(\mathrm{P}>0,05)$ kinerja pertumbuhan (PBBH, RKP), kecernaan nutrien dan IOFC. Dapat disimpulkan bahwa kinerja pertumbuhan kambing NE jantan muda tidak dipengaruhi oleh perlakuan konsentrat dengan level protein dan energi berbeda.
\end{abstract}

Kata Kunci: Energi, Protein, Kinerja, Kambing Silangan Anglo-Nubian dan Peranakan Ettawah

\section{PENDAHULUAN}

Kambing perah Peranakan Ettawah (PE) yang telah beradaptasi dengan lingkungan tropis di Indonesia produksi susunya masih rendah yaitu sekitar 0,5-1,2 1/hari (Sutama 
2008). Sedangkan kambing perah Anglo-Nubian (AN) yang berasal dari Inggris (Stemmer et al. 2009), berproduksi susu sebesar 2,65 liter/hari dengan masa laktasi 305 hari setahun. Untuk itu dilakukan pembentukan rumpun kambing perah baru melalui persilangan AngloNubian dengan Peranakan Ettawah (NE), yang diharapkan dapat meningkatkan produksi susu kambing perah. Praharani et al. (2016) melaporkan bahwa pertumbuhan dan kinerja reproduksi ternak F1 Anglo-Nubian vs Peranakan Ettawah (NE) lebih baik dibandingkan dengan ternak PE tetapi masih dibawah AN.

Manajemen pemeliharaan kambing silangan NE termasuk formulasi pemberian pakan berperan penting untuk membantu ternak dalam mengekspresikan potensi genetiknya secara maksimal. Pemberian pakan sesuai kebutuhan anak kambing perah lepas sapih ataupun kambing muda dapat mempercepat pertumbuhan dan diharapkan dapat memperbaiki kondisi pejantan maupun calon induk. Keseimbangan nutrisi dalam ransum menjadi sangat penting dan mempengaruhi kinerja pertumbuhan ternak bersangkutan. Kebutuhan nutrien kambing perah Anglo-Nubian maupun silangannya, masih terbatas informasinya. Protein dan energi merupakan komponen nutrien utama dalam pertumbuhan kambing. Untuk mendapatkan besarnya kebutuhan energi dan protein kambing berdasarkan bobot badan dan status fisiologis mengacu pada rekomendasi yang dianjurkan oleh institusi international seperti National Research Council (NRC), namun harus diperhatikan adaptasi ternak tersebut terhadap jenis pakan dan kondisi lingkungannya.

Hasil penelitian terdahulu (Supriyati et al. 2014) mengenai kebutuhan protein dan energi pada kambing PE adalah lebih besar dari pada yang direkomendasikan oleh NRC (1981). Sahlu et al. (2004) melaporkan bahwa kebutuhan protein dan energi untuk kambing perah selama pertumbuhan sebesar 86,2 g/hari dan 2,92 Mkal/kg energi metabolis (EM) untuk BB $40 \mathrm{~kg}$ dan PBHH 125 g/hari. Selanjutnya Aregheore et al. (2003) melaporkan bahwa kinerja kambing silangan Anglo-Nubian dan kambing lokal di Samoa pada periode pertumbuhan terbaik dihasilkan dari pakan yang mengandung 13,4\% protein kasar (PK) dan 3,2 Mkal/kg energi kasar (EK). Rekomendasi terkini (NRC 2007) mengenai kebutuhan protein dan energi untuk kambing perah dengan bobot badan (BB) 15 $\mathrm{kg}$ dan pertambahan bobot badan harian $(\mathrm{PBBH}) 100 \mathrm{~g} / \mathrm{hari}$ sebesar 1,69 Mkal/kg energy metabolis (EM), $74 \mathrm{~g}$ undegradable intake protein (UIP) dan $42 \mathrm{~g}$ degradable intake protein (DIP).

Bervariasinya kebutuhan protein dan energi kambing perah maupun kambing perah silangan seperti dilaporkan di atas dan belum tersedianya kebutuhan protein maupun energi untuk kambing silangan NE, maka tujuan penelitian ini adalah mengkaji kinerja pertumbuhan kambing NE jantan muda yang diberi konsentrat dengan level protein dan energi berbeda.

\section{MATERI DAN METODE}

\section{Ternak dan percobaan pakan}

Sebanyak 24 ekor kambing silangan NE jantan muda dengan rata-rata bobot awal sebesar 14,40 $\pm 2,99 \mathrm{~kg}$ /ekor dikelompokkan menjadi tiga perlakuan konsentrat dengan masing-masing delapan ulangan. Ternak dipelihara selama 16 minggu pada kandang individu yang berukuran $1,6 \times 1,0 \mathrm{~m}^{2}$. Kandang berada dalam gedung yang beratapkan asbes dimana setiap kandang terbuat dari metal dengan lantai kayu dengan tempat pakan terbuat dari metal dan kayu. Obat cacing diberikan sebelum percobaan dimulai.

Konsentrat disusun sebagai berikut: protein kasar (PK) 15\%, UIP 2,2\% (P1); PK 16\%, UIP 5,1\% (P2) dan PK 17\%, UIP 5,6\% (P3) serta level energi metabolis (EM) sebesar 2,6 $\mathrm{Mkal} / \mathrm{kg}$ (E1); 2,8M kal/kg (E2) dan 3,0 Mkal/kg (E3). Tiga macam perlakuan konsentrat 
disusun sebagai berikut: $\mathrm{K} 1=\mathrm{P} 1 \mathrm{E} 1, \mathrm{~K} 2=\mathrm{P} 2 \mathrm{E} 2$, dan $\mathrm{K} 3=\mathrm{P} 3 \mathrm{E} 3$, dengan rasio $\mathrm{PK}$ terhadap EM untuk K1, K2 dan K3 yaitu sama $(5,7)$.

Pakan dasar yang diberikan adalah rumput raja, campuran legum dan konsentrat. Konsentrat disusun antara lain dari dedak padi, jagung giling, bungkil kelapa, bungkil kacang kedele, polard, bungkil inti sawit, molases, dan campuran mineral dan vitamin. Rumput diberikan ad libitum, 500-800 g campuran legum (50\% kaliandra dan 50\% glirisidia) dan konsentrat diberikan sekitar 2\% dari BB. Konsentrat diberikan secara terpisah. Air minum di ember/nipple tersedia setiap saat. Pakan yang dikonsumsi diukur setiap hari sedangkan BB diukur setiap dua minggu.

Parameter kinerja pertumbuhan yang diestimasi adalah: (1) Konsumsi nutrien pakan meliputi kadar air (KA), protein kasar (PK), UIP, DIP, energi metabolis (EM dihitung menurut NRC 1981), serat deterjen netral (SDN), serat deterjen asam (SDA), kalsium (Ca) dan fosfor (P); (2) Pertambahan bobot badan harian (PBBH); (3) Rasio konversi pakan (RKP) diukur berdasarkan konsumsi BK/PBBH; dan (4) Koefisien cerna nutrien menggunakan metode koleksi total selama 10 hari.

Parameter lainnya yang ditetapkan adalah rasio pendapatan terhadap biaya produksi (income over feed cost/IOFC). Dimana harga rumput dan legum berdasarkan bahan kering adalah Rp 1.500 dan Rp 2.000 per kg, sedangkan harga konsentrat K1, K2 dan K3 masingmasing adalah Rp. 3.600; Rp. 4.000; dan Rp. 4.900 per kg dengan harga jual kambing Rp. 75.000 per kg.

\section{Analisis kimia}

Analisis kimia dilakukan pada rumput, legum, konsentrat dan feses meliputi bahan kering $(\mathrm{BK})$, protein kasar $(\mathrm{PK})$, energi kasar $(\mathrm{EK})$, serat deterjen netral $(\mathrm{SDN})$, serat deterjen asam (SDA), abu, kalsium $(\mathrm{Ca})$ dan fosfor $(\mathrm{P})$ berdasarkan metode AOAC (AOAC 2012) yang telah dimodifikasi di Laboratorium Pelayanan Kimia Analitik Balitnak. Kadar EK ditetapkan dengan menggunakan kalorimeter (Adiabatic Bomb, Parr Instrument Co), di mana nilai yang diperoleh selanjutnya digunakan untuk menghitung energi termetabolis (EM) seperti dijelaskan oleh NRC (1981). Kadar UIP dan DIP ditetapkan berdasarkan perhitungan.

\section{Analisis statistik}

Pengaruh perlakuan konsentrat terhadap konsumsi pakan, PBBH, RPK, IOFC dan kecernaan nutrien pakan dianalisis menggunakan prosedur ANOVA - General Linear Model (GLM) dari SAS (SAS Institute Inc. 2002). Bila ada perbedaan di antara perlakuan selanjutnya dilakukan Duncan's Multiple Range Test pada level signifikant $\mathrm{P}<0,05$.

\section{HASIL DAN PEMBAHASAN}

\section{Komposisi kimia pakan}

Tabel 1 menampilkan hasil analisis komposisi kimia rumput raja, campuran legum, dan konsentrat perlakuan. Kadar UIP dan DIP dalam konsentrat dihitung pada saat menyusun konsentrat. Sedangkan kadar UIP dan DIP rumput dan legum diperoleh dari referensi. 
Tabel 1. Komposisi kimia pakan yang diberikan pada kambing NE jantan muda selama 16 minggu percobaan berdasarkan bahan kering

\begin{tabular}{|c|c|c|c|c|c|}
\hline \multirow{2}{*}{ Variables } & \multirow{2}{*}{$\begin{array}{c}\text { Rumput } \\
\text { Raja }\end{array}$} & \multirow{2}{*}{$\begin{array}{l}\text { Campuran } \\
\text { legum }\end{array}$} & \multicolumn{3}{|c|}{ Konsentrat } \\
\hline & & & $\mathrm{K} 1$ & $\mathrm{~K} 2$ & K3 \\
\hline Kadar air $(\%)$ & 89,39 & 80,20 & 10,98 & 11,06 & 12,17 \\
\hline Protein kasar (\%) & 8,18 & 26,10 & 14,94 & 16,03 & 17,31 \\
\hline $\begin{array}{l}\text { Undegradable intake protein } \\
\text { (UIP) }(\%)\end{array}$ & 4,08 & 7,77 & 1,98 & 3,32 & 6,19 \\
\hline $\begin{array}{l}\text { Degradable intake protein } \\
\text { (DIP) }(\%)\end{array}$ & 4,10 & 18,32 & 12,16 & 11,63 & 10,58 \\
\hline Energi termetabolis (Mkal/kg) & 2,75 & 3,26 & 2,63 & 2,80 & 2,98 \\
\hline Serat deterjen netral (SDN) (\%) & 71,35 & 46,98 & 29,15 & 29,23 & 28,50 \\
\hline Serat deterjen asam (SDA) (\%) & 48,68 & 28,36 & 17,19 & 16,84 & 14,15 \\
\hline $\mathrm{Abu}(\%)$ & 12,79 & 7,99 & 7,59 & 7,43 & 8,02 \\
\hline Kalsium (\%) & 0,22 & 1,14 & 1,12 & 0,85 & 0,83 \\
\hline Fosfor $(\%)$ & 0,12 & 0,28 & 0,94 & 0,62 & 0,66 \\
\hline
\end{tabular}

$\mathrm{K} 1=15 \% \mathrm{PK}+2,6 \mathrm{Mkal} \mathrm{EM} / \mathrm{kg} ; \mathrm{K} 2=16 \% \mathrm{PK}+2,8 \mathrm{Mkal} \mathrm{EM} / \mathrm{kg} ; \mathrm{K} 3=17 \% \mathrm{PK}+3,0 \mathrm{Mkal}$ $\mathrm{EM} / \mathrm{kg}$

\section{Konsumsi nutrien}

Konsumsi pakan erat kaitannya dengan sifat fisik dan kimia pakan, bobot hidup dan status fisiologi ternak (NRC 2007). Tabel 2 menampilkan pengaruh perlakuan konsentrat yang berbeda level protein dan energi terhadap konsumsi nutrien pada kambing NE jantan muda selama 16 minggu percobaan.

Perlakuan konsentrat mempengaruhi konsumsi harian legum, UIP, DIP, SDA, Ca dan $\mathrm{P}(\mathrm{P}<0,05)$. Namun tidak mempengaruhi konsumsi rumput, konsentrat, total $\mathrm{BK}$, rasio konsumsi hijaun terhadap total BK, BO, PK, EM, dan SDN (P>0,05). Rata-rata konsumsi harian total BK pada ternak NE yang dikandangkan secara individu dari masing-masing konsentrat yang berbeda level protein dan energi menunjukkan perbedaan yang tidak nyata $(\mathrm{P}>0,05)$. Rata-rata konsumsi BK pada penelitian ini adalah 545,51 g/ekor/hari (1,03 kali NRC 2007), nilai ini sedikit lebih besar daripada kebutuhan BK yang disarankan oleh NRC (2007) yakni $530 \mathrm{~g} /$ hari dengan BB $15 \mathrm{~kg}$ untuk mendapatkan pertumbuhan kambing perah berkisar antara $100 \mathrm{~g} / \mathrm{ekor} /$ hari. Besarnya rata-rata konsumsi harian total $\mathrm{BK}$ ransum untuk perlakuan konsentrat K1, K2 dan K3 setara dengan 2,89; 2,85; dan 2,89\% dari ratarata BB-nya. Nilai ini lebih rendah dari kisaran kebutuhan BK yang disarankan oleh NRC (2007) yakni sebesar 3,0-3,5\% dari BB.

Rata-rata konsumsi protein kasar $(\mathrm{PK})$ tidak dipengaruhi secara nyata $(\mathrm{P}>0,05)$ oleh perbedaan level protein dalam konsentrat pada ternak kambing NE jantan (Tabel 2), namun mempengaruhi konsumsi UIP dan DIP $(\mathrm{P}<0,05)$. Rata-rata konsumsi PK untuk ketiga perlakuan adalah 86,98 g/ekor/hari, setara dengan 1,18 kali NRC (1981) yang direkomendasikan. Kebutuhan protein menurut NRC (1981) untuk kambing dengan ratarata $20 \mathrm{~kg}$ BB dan rata-rata $100 \mathrm{~g} / \mathrm{ekor} / \mathrm{hari}$ PBBH yaitu sebesar $74 \mathrm{~g}$. Persentase rata-rata konsumsi PK terhadap total konsumsi BK adalah 15,91\%. Supriyati et al. (2014) melaporkan bahwa kebutuhan protein untuk kambing PE sebesar 1,34 kali dari rekomendasi NRC (1981). Sedangkan Sahlu et al. (2004) melaporkan bahwa kebutuhan protein metabolis kambing perah selama pertumbuhan sebesar $3,07 \mathrm{~g} / \mathrm{kg} \mathrm{BB}{ }^{0.75}+0,290 \mathrm{~g} / \mathrm{g}$ 
PBBH. Kebutuhan protein kambing NE jantan $(15,91 \%)$ pada percobaan ini lebih besar dari pada yang dilaporkan oleh Aregheore et al. (2003) di mana kinerja kambing silangan Anglo-Nubian dan kambing lokal di Samoa pada periode pertumbuhan terbaik dihasilkan dari pakan yang mengandung 13,4\% PK. Perbedaan ini kemungkinan disebabkan oleh jenis ternak, pakan dan lingkungan dimana kambing tersebut diternakkan.

Tabel 2. Konsumsi nutrien kambing NE jantan yang diberi konsentrat dengan level protein dan energi berbeda namun rasionya seimbang selama 16 minggu percobaan

\begin{tabular}{|c|c|c|c|c|c|c|}
\hline \multirow{2}{*}{ Parameter } & \multicolumn{4}{|c|}{ Konsentrat } & \multirow{2}{*}{ SEM } & \multirow{2}{*}{ Nilai P } \\
\hline & K 1 & K 2 & K3 & Rata-rata & & \\
\hline \multicolumn{7}{|l|}{ Bahan kering } \\
\hline Rumput (g) & 141,400 & 139,720 & 132,250 & 137,790 & 24,530 & 0,7330 \\
\hline Legum $(\mathrm{g})$ & $119,310^{\mathrm{a}}$ & $92,830^{\mathrm{b}}$ & $96,880^{\mathrm{b}}$ & 103,010 & 14,390 & 0,0030 \\
\hline Konsentrat (g) & 331,760 & 304,870 & 277,500 & 304,710 & 51,620 & 0,1350 \\
\hline Total $(\mathrm{g})$ & 592,470 & 537,430 & 506,620 & 545,510 & 71,790 & 0,0750 \\
\hline Rasio hijauan/total BK & 0,440 & 0,440 & 0,460 & 0,450 & 0,048 & 0,6100 \\
\hline Bahan organik (g) & $539,690^{\mathrm{a}}$ & $489,500^{\mathrm{ab}}$ & $459,730^{\mathrm{b}}$ & 496,300 & 65,510 & 0,0690 \\
\hline Protein kasar (g) & 92,270 & 84,530 & 84,140 & 86,980 & 11,250 & 0,2860 \\
\hline $\operatorname{UIP}(\mathrm{g})$ & $21,520^{\mathrm{c}}$ & $22,970^{\mathrm{b}}$ & $30,300^{\mathrm{a}}$ & 24,840 & 2,780 & $<0,0001$ \\
\hline $\mathrm{DIP}(\mathrm{g})$ & $68,000^{\mathrm{a}}$ & $58,190^{\mathrm{b}}$ & $52,530^{\mathrm{b}}$ & 59,570 & 8,160 & 0,0040 \\
\hline Energi metabolis (Mkal/kg) & 1,650 & 1,541 & 1,507 & 1,566 & 0,200 & 0,3420 \\
\hline $\operatorname{SDN}(g)$ & $253,650^{\mathrm{a}}$ & $232,420^{\mathrm{ab}}$ & $218,960^{\mathrm{b}}$ & 235,010 & 30,380 & 0,0940 \\
\hline SDA (g) & $159,700^{\mathrm{a}}$ & $145,680^{\mathrm{ab}}$ & $131,120^{\mathrm{b}}$ & 145,500 & 19,400 & 0,0260 \\
\hline $\mathrm{Ca}(\mathrm{g})$ & $5,380^{\mathrm{a}}$ & $3,950^{\mathrm{b}}$ & $3,690^{\mathrm{b}}$ & 4,340 & 0,950 & 0,0030 \\
\hline$P(g)$ & $3,620^{\mathrm{a}}$ & $2,320^{\mathrm{b}}$ & $2,260^{\mathrm{b}}$ & 2,740 & 0,740 & $<0,0001$ \\
\hline
\end{tabular}

$\mathrm{K} 1=15 \% \mathrm{PK}+2,6 \mathrm{Mkal} \mathrm{EM} / \mathrm{kg} ; \mathrm{K} 2=16 \% \mathrm{PK}+2,8 \mathrm{Mkal} \mathrm{EM} / \mathrm{kg} ; \mathrm{K} 3=17 \% \mathrm{PK}+3,0 \mathrm{Mkal}$

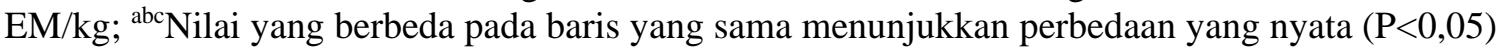

Rata-rata konsumsi protein (UIP dan DIP) adalah 86,98 g/ekor/hari (24,84 dan 59,57 g/ekor/hari). Sedangkan persentase konsumsi protein (UIP dan DIP) terhadap total konsumsi BK adalah 15,47\%. Kebutuhan protein (UIP dan DIP) menurut NRC (2007) untuk kambing perah dengan $\mathrm{BB} 15 \mathrm{~kg}$ dengan PBBH 100 g/ekor masing-masing yaitu sebesar 116 g/ekor/hari (74 g/ekor/hari UIP dan 42 g/ekor/hari DIP). Dengan perlakuan pakan konsentrat seperti pada penelitian ini ternyata asupan UIP $(24,84 \mathrm{~g} / \mathrm{ekor} / \mathrm{hari})$ lebih rendah dari anjuran NRC (2007) yaitu sebesar 74 g/ekor/hari. Namun asupan DIP (59,57 g/ekor/hari) lebih besar dari anjuran NRC (2007) yaitu sebesar 42 g/ekor/hari. Hal ini berdampak pada besarnya nilai PBBH yang dihasilkan di bawah 100 g/ekor/hari, di mana pada penelitian ini diperoleh PBBH sebesar 86,57 g/ekor/hari. Perbedaan level UIP dan DIP pada percobaan ini tidak mempengaruhi PBBH ternak kambing. Hal ini sejalan seperti dilaporkan oleh Yulistiani et al. (2015) bahwa perbedaan level UIP dalam pakan tidak mempengaruhi terhadap PBBH pada empat bangsa domba.

Rata-rata asupan EM tidak dipengaruhi $(\mathrm{P}>0,05)$ oleh perbedaan level protein dan energi dalam konsentrat pada ternak kambing NE (Tabel 2). Asupan EM untuk masingmasing perlakuan K1, K2 dan K3 adalah 1,02; 1,10 dan 1,12 kali NRC (2007). Rata-rata asupan EM untuk ketiga perlakuan yaitu 1,566 Mkal EM/kg (1,08 kali NRC), lebih rendah dari anjuran NRC (2007). Kebutuhan energi yang disarankan oleh NRC (2007) untuk 
kambing perah $15 \mathrm{~kg}$ BB dengan $100 \mathrm{~g}$ PBBH yaitu sebesar 1,69 Mkal EM/kg. Dengan perlakuan perbedaan level protein dan energi pada konsentrat pada penelitian ini tercapai PBBH diatas 75 g/ekor/hari namun di bawah 100 g/ekor/hari (Tabel 3). Aregheore et al. (2003) mengestimasi kebutuhan energi yang optimal pada kambing silangan AngloNubian dan lokal Samoa sebesar 3,2 Mkal EM/kg (80,87\% TDN). Sahlu et al. (2004) melaporkan bahwa kebutuhan energi metabolism (EM) untuk kambing pada periode pemeliharan $\left(\mathrm{EM}_{\mathrm{m}}\right)$ dan pertumbuhan $\left(\mathrm{EM}_{\mathrm{g}}\right)$ masing-masing adalah $139 \mathrm{kkal} / \mathrm{kg} \mathrm{BH}^{0,75}$ dan 55,2 kkal/g PBHH, setara dengan 2,92 Mkal EM/kg (80,91\% TDN) untuk $40 \mathrm{~kg} \mathrm{BB}$ dan $125 \mathrm{~g} / \mathrm{ekor} / \mathrm{hari} \mathrm{PBHH}$.

Rata-rata konsumsi SDN tidak dipengaruhi $(\mathrm{P}>0,05)$ oleh perbedaan level protein dan energi dalam konsentrat pada ternak kambing NE. Rata-rata persentase SDN terhadap total konsumsi BK pada kambing NE kambing jantan adalah 42,81; 43,24; dan 43,21\%. Besarnya konsumsi SDN tersebut ternyata sesuai dengan yang disitir oleh Lu et al. (2008) yakni $43 \%$ dari konsumsi BK untuk mendapatkan pertumbuhan yang optimal yaitu 100 g/ekor/hari.

Rata-rata konsumsi SDA dipengaruhi secara nyata $(\mathrm{P}<0,05)$ oleh perbedaan level protein dan energi dalam konsentrat pada ternak kambing NE. Rata-rata persentase SDA terhadap total konsumsi BK masing-masing untuk perlakuan K1, K2 dan K3 adalah 26,95; 27,10; dan 25,88\%. Besarnya konsumsi SDA tersebut ternyata lebih besar dengan yang dilaporkan oleh Lu et al. (2008) yakni sebesar 23\% dari konsumsi BK untuk mendapatkan pertumbuhan yang optimal. Besarnya kandungan serat pada pakan mempengaruhi pertumbuhan, semakin besar kandungan seratnya maka sering terjadi pertumbuhan yang semakin lambat. Pada penelitian ini dimana kandungan serat (SDA) nya lebih besar daripada rekomendasi ( $\mathrm{Lu}$ et al. 2008) sehingga PBBH yang optimal (100 g/ekor/hari) tidak tercapai.

Perbedaan level protein dan energi pada konsentrat mempengaruhi konsumsi Ca dan $\mathrm{P}$ secara nyata $(\mathrm{P}<0,05)$ pada kambing $\mathrm{NE}$. Rata-rata konsumsi harian $\mathrm{Ca}$ adalah 4,34 g/ekor/hari untuk kambing NE, lebih besar dari anjuran NRC (2007). NRC (2007) merekomendasikan kebutuhan $\mathrm{Ca}$ pada kambing perah dengan $15 \mathrm{~kg}$ BB untuk mendapatkan pertumbuhan $100 \mathrm{~g} /$ ekor/hari yakni 3,7 g/ekor/hari. Sedangkan rata-rata konsumsi $\mathrm{P}$ harian adalah $2,74 \mathrm{~g} / \mathrm{ekor} /$ hari ternyata lebih besar daripada yang dianjurkan oleh NRC (2007). NRC (2007) merekomendasikan kebutuhan P pada kambing perah muda dengan $15 \mathrm{~kg}$ BB yakni sebesar 1,8 g/ekor/hari untuk mendapatkan pertumbuhan 100 g/ekor/hari.

Dari hasil pengamatan diatas dapat disimpulkan bahwa perlakuan konsentrat K1, K2 dan K3 (2\% BB) dengan pakan dasar rumput Raja ad libitum dan campuran legum memenuhi standard kebutuhan energi dan protein pakan kambing NE periode pertumbuhan yang dianjurkan oleh institusi international (Kearl 1982 maupun NRC 1981). Namun bila berdasarkan NRC (2007) maka kebutuhan protein (UIP dan DIP) dan EM-nya untuk mendapatkan PBBH sebesar 100 g/ekor/hari adalah 1,38 kali dan 1,08 kalinya dari konsentrasi konsentrat perlakuan.

\section{Kinerja pertumbuhan}

Tabel 3 menunjukan kinerja kambing NE jantan lepas sapih yang diberi pakan konsentrat berbeda level protein dan energi dengan rasio protein/energi yang sama (seimbang) selama 16 minggu percobaan. Hasil pengamatan perlakuan konsentrat K1, K2 dan K3 tidak mempengaruhi kinerja kambing (BB akhir, PBBH, RKP) dan IOFC secara nyata $(\mathrm{P}>0,05)$. 
Bobot awal dan bobot akhir percobaan menunjukkan tidak ada perbedaan yang nyata $(\mathrm{P}>0,05)$ di antara perlakuan konsentrat. $\mathrm{PBBH}$ tidak berbeda nyata $(\mathrm{P}>0,05)$ di antara perlakuan konsentrat selama 16 minggu percobaan, dengan rata-rata 86,57 g/ekor/hari. Besarnya PBBH masih di bawah anjuran NRC (2007) yaitu 100 g/hari. Dengan meningkatnya kandungan PK sebesar $1-2 \%$ dan EM 0,2-0,4 Mkal/kg ternyata tidak meningkatkan $\mathrm{PBBH}$. Hal ini dikarenakan perbedaan level yang rendah serta konsentrat disusun iso-rasio protein/energi. Untuk mencapai besarnya rata-rata $\mathrm{PBBH} 100 \mathrm{~g}$ pada $\mathrm{BB}$ $15 \mathrm{~kg}$ dipengaruhi oleh manajemen pemeliharaan, jenis kelamin dan breed kambing. Hasil pada penelitian ini berbeda dengan hasil yang dilaporkan oleh Lu \& Potchoiba (1990) bahwa pertumbuhan kambing AN yang diberi pakan dengan konsumsi BK $926 \mathrm{~g} / \mathrm{hari}$ adalah 111 g/ekor/hari selama 16 minggu percobaan. Demikian pula Aregheore et al. (2003) melaporkan bahwa kambing silangan Anglo-Nubian dan lokal di Samoa yang diberi perlakuan pakan yang berbeda level protein dan energi menunjukkan PBBH yang berbeda. Pada kambing yang mendapatkan pakan dengan kandungan 13,4\% PK dan 3,2 Mkal/kg EK (130 g/ekor PBBH) lebih besar PBBH-nya dibandingkan dengan perlakuan pakan 16,6\% PK dan 2,7 Mkal/kg EK (95 g/ekor PBBH) serta pakan 12,4\% PK dan 3,44 $\mathrm{Mkal} / \mathrm{kg}$ EK (89 g/ekor PBBH).

Tabel 3. Kinerja kambing NE jantan muda yang diberi pakan berbeda level protein dan energi dengan rasio protein/energi yang seimbang selama percobaan

\begin{tabular}{|c|c|c|c|c|c|c|}
\hline \multirow{2}{*}{ Variabel } & \multicolumn{4}{|c|}{ Konsentrat } & \multirow{2}{*}{ SEM } & \multirow{2}{*}{ Nilai P } \\
\hline & K 1 & K 2 & K3 & Rata-rata & & \\
\hline Bobot badan awal (kg) & 15,910 & 14,080 & 13,180 & 14,390 & 2,840 & 0,171 \\
\hline Bobot badan akhir $(\mathrm{kg})$ & 25,900 & 23,680 & 22,680 & 24,080 & 4,150 & 0,302 \\
\hline PBBH (g/ekor/hari) & 89,170 & 85,720 & 84,820 & 86,57 & 17,410 & 0,789 \\
\hline Rasio konversi pakan & 6,790 & 6,500 & 6,030 & 6,440 & 1,100 & 0,393 \\
\hline IOFC & 3,300 & 3,470 & 3,530 & 3,440 & 0,530 & 0,661 \\
\hline
\end{tabular}

$\mathrm{K} 1=15 \% \mathrm{PK}+2,6 \mathrm{Mkal} \mathrm{EM} / \mathrm{kg} ; \mathrm{K} 2=16 \% \mathrm{PK}+2,8 \mathrm{Mkal} \mathrm{EM} / \mathrm{kg} ; \mathrm{K} 3=17 \% \mathrm{PK}+3,0 \mathrm{Mkal}$ $\mathrm{EM} / \mathrm{kg} ; \mathrm{PBBH}=$ Pertambahan bobot badan harian; Rasio konversi pakan $=$ Konsumsi $/ \mathrm{PBBH}$; IOFC = Income over feed cost (benefit/cost)

Rasio konversi pakan (RKP) kambing NE jantan muda tidak dipengaruhi oleh perlakuan konsentrat yang berbeda level protein dan energi. Perbedaan asupan UIP dan DIP pada penelitian ini tidak mempengaruhi RKP. Hal ini sejalan dengan hasil yang dilaporkan Yulistiani et al. (2015) bahwa perbedaan level DIP tidak mempengaruhi RKP. Nilai RKP pada penelitian ini lebih baik dibanding hasil penelitian yang dilaporkan oleh Aregheore et al. (2003).

Efisiensi ekonomi yang dihitung berdasarkan harga jual kambing dikurangi biaya pakan (IOFC) seperti ditampilkan pada Tabel 3 menunjukkan bahwa perlakuan konsentrat tidak berpengaruh pada nilai IOFC untuk kambing jantan. Nilai rata-rata diperoleh 3,44.

\section{Koefisien cerna nutrien}

Tabel 4 menampilkan koefisien cerna nutrien pakan pada kambing NE jantan muda yang diberi pakan berbeda level protein dan energi dalam konsentrat pada periode pertmbuhan. Perlakuan konsentrat yang berbeda level protein dan energi tidak mempengaruhi $(\mathrm{P}>0,05)$ kecernaan nutrient $(\mathrm{BK}, \mathrm{BO}, \mathrm{PK}, \mathrm{EK}, \mathrm{SDN}$ dan SDA) pakan. 
Tabel 4. Koefisien cerna nutrien pakan kambing NE jantan yang diberi konsentrat berbeda level protein dan energi pada periode pertumbuhan

\begin{tabular}{|c|c|c|c|c|c|c|}
\hline \multirow{2}{*}{ Variabel } & \multicolumn{4}{|c|}{ Konsentrat } & \multirow{2}{*}{ SEM } & \multirow{2}{*}{ Nilai $\mathrm{P}$} \\
\hline & $\mathrm{K} 1$ & $\mathrm{~K} 2$ & K3 & Rata-rata & & \\
\hline Bahan kering (\%) & 75,480 & 75,580 & 76,030 & 75,720 & 2,150 & 0,934 \\
\hline Bahan organik (\%) & 78,070 & 76,680 & 77,490 & 77,410 & 2,590 & 0,754 \\
\hline Protein kasar (\%) & 77,740 & 78,420 & 79,850 & 78,760 & 1,860 & 0,349 \\
\hline Energi kasar (\%) & 74,900 & 75,470 & 76,520 & 75,700 & 2,110 & 0,604 \\
\hline $\operatorname{SDN}(\%)$ & 63,500 & 62,910 & 63,310 & 63,220 & 3,540 & 0,975 \\
\hline $\operatorname{SDA}(\%)$ & 56,540 & 57,550 & 56,540 & 57,630 & 3,940 & 0,808 \\
\hline $\mathrm{Abu}(\%)$ & 60,330 & 62,650 & 62,040 & 61,800 & 3,710 & 0,717 \\
\hline
\end{tabular}

$\mathrm{K} 1=15 \% \mathrm{PK}+2,6 \mathrm{Mkal} \mathrm{EM} / \mathrm{kg} ; \mathrm{K} 2=16 \% \mathrm{PK}+2,8 \mathrm{Mkal} \mathrm{EM} / \mathrm{kg} ; \mathrm{K} 3=17 \% \mathrm{PK}+3,0 \mathrm{Mkal}$ $\mathrm{EM} / \mathrm{kg}$

Perlakuan konsentrat yang berbeda level protein dan energi pada kambing NE jantan muda tidak mempengaruhi $(\mathrm{P}>0,05)$ kecernaan nutrien pakan. Hal ini dikarenakan perbedaan level PK dan EM yang rendah, masing-masing yaitu 1-2\% dan 0,2-0,4 Mkal/kg yang berdampak pada asupan nutrien pakan PK dan EM yang tidak berbeda nyata (Tabel 2). Selain itu konsentrat disusun iso rasio PK terhadap EM, seperti dilaporkan oleh Aregheore et al. (2003) bahwa pakan yang disusun seimbang antara PK dan EK (13,4\% PK dan 13,4 MJ/kg EK) menghasilkan nilai kecernaan PK dan EK yang optimal, masingmasing yaitu 72,9 dan $72,6 \%$.

Perbedaan konsumsi UIP dan DIP (Tabel 2) tidak mempengaruhi koefisien cerna nutrien. Hal ini sesuai dengan hasil yang dilaporkan oleh Yulistiani et al. (2015), di mana perbedaan level UIP tidak mempengaruhi kecernaan BK, PK, SDN, SDA dan energi pada domba.

\section{KESIMPULAN}

Dari hasil pengamatan, ternyata kinerja pertumbuhan kambing NE jantan muda yang diberi konsentrat dengan level protein dan energi berbeda (rasionya seimbang) mempengaruhi konsumsi harian BK legum, UIP, DIP, SDA, Ca dan P; namun tidak mempengaruhi kinerja pertumbuhan (PBBH, RKP), kecernaan nutrien pakan dan IOFC kambing NE.

\section{DAFTAR PUSTAKA}

Aregheore EM, Kumar A, Manueli P. 2003. Dietary levels of energy and protein for optimal growth of Crossbred Anglo-Nubian goats in Samoa. Int J Agric Biol. 5:428-431.

Lu CD, Potchoiba MJ. 1990. Feed intake and weight gain of growing goats fed diets of various energy ang protein levels. J Anim Sci. 68:1751-1759.

Lu CD, Kawas JR, Mahgoub OG. 2008. Review recent advancements in fiber digestion and utilization in goats. Trop Subtrop Agroecosyst. 9:65-72.

NRC. 1981. Nutrient requirements of goats. Washington DC (USA): National Academy Press.

NRC. 2007. Nutrient requirements of small ruminants. Washington DC (USA): National Academy Press. 
Praharani L, Supriyati, Krisnan R. 2016. A preleminary study on some reproductive traits and heterosis effects of Anglo-Nubian and Ettawah Grade crossbred does. In: Yulistiani D, Wardhana AH, Inounu I, Bahri S, Iskandar S, Wina E, Ginting SP, Tarigan S, Tiesnamurti B, Romjali E et al., editors. Promoting Livestock And Veterinary Technology For Sustainable Rural Livestock Development. Proceedings of International Seminar on Livestock Production and Veterinary Technology. Denpasar, 10-12 ${ }^{\text {th }}$ August 2016. Bogor (Indonesia): Puslitbangnak. p. 252-260.

Sahlu T, Goetsch AL, Luo J, Nsahlai IV, Moore JE, Galyean ML, Owens FN, Ferrel CL, Johnson ZB. 2004. Nutrient requirements of goats: Developed equations, other considerations and future research to improve them. Small Rumin Res. 53:191-219.

Supriyati, Praharani L, Budiarsana IGM, Sutama I-K. 2014. Pengaruh perbedaan level protein pada konsentrat terhadap kinerja kambing Peranakan Ettawah betina muda. Dalam: Pamungkas D, Widiawati Y, Noor SM, Purwantari ND, Widiastuti R, Brahmantyo B, Herawati T, Kusumaningsih A, Handiwirawan E, Puastuti W, penyunting. Teknologi Peternakan dan Veteriner Mendukung Pertanian Bioindustri Berkelanjutan. Prosiding Seminar Nasional Teknologi Peternakan dan Veteriner. Malang, 12-14 Agustus 2014. Bogor (Indonesia): Puslitbangnak. hlm. 440-446.

Sutama I-K. 2008. Pemanfaatan sumberdaya ternak lokal sebagai ternak perah mendukung peningkatan produksi susu nasional. Wartazoa 18:207-217.

Stemmer A, Siegmund-Schultze M, Gall C, Zárate A. 2009. Development and worldwide distribution of the Anglo Nubian Goat. Trop Subtrop Agroecosyst. 11:185.

Yulistiani D, Naufaliah N, Kardaya D, Subandriyo. 2015. Kecernaan nutrisi dan pertumbuhan lima rumpun domba pada beberapa tingkat kandungan protein tidak terdegradasi. JITV 20:23-30.

\section{DISKUSI}

\section{Pertanyaan}

Mengapa Standar deviasi berat badan ternak terlalu tinggi, apakah ada kesalahan menentukan levelnya? Apakah penelitian ini responsif terhadap ternak kambing?

\section{Jawaban}

Pada penelitian ini standar deviasi tidak termasuk tinggi, karena masih jauh lebih kecil dari nilai rata-rata.

Pada penelitian ini feed aditif sangat responsif terhadap konsumsi ternak kambing. 